УДК 616.31(07.07)

\title{
ЗАСТОСУВАННЯ МЕТОДУ КОНКУРЕНТНИХ АБО КОРПОРАТИВНИХ ГРУП ПРИ ПРОВЕДЕННІ СЕМІНАРСЬКОГО ЗАНЯТТЯ НА ТЕМУ “КОМПЛЕКСНЕ ЛІКУВАННЯ ГЕНЕРАЛІЗОВАНОГО ПАРОДОНТИТУ ЩЕЛЕП”
}

\author{
В. В. Федько, У. Д. Матолич, А. В. Нетлюх, Р. В. Гайдук \\ Львівський національний медичний університет імені Данила Галиџького
}

\section{APPLICATION OF THE METHOD OF COMPEETING OR CORPORATING GROUPS DURING PRACTICAL CLASS ON THEME "COMPLEX TREATMENT OF GENERALIZED PARODONTITIS OF JAWS"}

\author{
V. V. Fedko, U. D. Matolych, A. V. Netliukh, R. V. Hayduk \\ Lviv National Medical University by Danylo Halytskyi
}

\begin{abstract}
У статті викладено досвід авторів при проведенні практичних занять з хірургічної стоматології методом інтерактивного навчання (конкурентні або корпоративні групи), якість якого значно покращується.
\end{abstract}

The article adduces the experience of authors using method of interactive teaching (compeeting or corporating groups) during practical classes of surgical dentistry, quality of which is significantly increasing.

Викладання є мистеитво, а не ремесло у иьому корінь учительської справи

М. О. Рибникова

Вступ. Метод конкурентних або корпоративних груп дозволяє:

- формувати особистість зі здатністю до клінічного мислення;

- якісно підвищувати рівень професійної підготовки студента;

- стимулювати інтерес до навчання через активізацію раніше засвоєних знань, навичок та вмінь;

- виробляти вміння аналізувати ситуацію, аргументувати свою думку й толерантно вести дискусію;

- удосконалювати навички клінічного застосування теоретичних знань під час тренінгу на макетах або в процесі лікування хворого;

- орієнтувати студента на пошукову діяльність;

- підвищувати рівень включеності в роботу $[4,5,6]$.

При груповій роботі інтерактивного навчання (конкурентні або корпоративні групи) існують певні правила роботи:

- кожен учасник має можливіть висловитися, якщо в нього є бажання;
- всі учасники групи поважають цінності та погляди кожного, навіть, якщо не згодні з ними;

- обговорюються ідеї, пропозиції, а не люди, що їх висловили;

- кожен учасник, навіть захищаючи свою точку зору, відкритий для сприйняття чужих ідей, думок та інтересів інших учасників;

- всі розбіжності, конфлікти, що виникають під час роботи, розв'язуються мирним шляхом, з урахуванням інтересів учасників та правил роботи;

- всі учасники прагнуть створити відкриту, ділову та дружню атмосферу [1].

Основна частина. Студентів розділяють на дві чи більше груп, які конкурують між собою у вирішенні певної клінічної проблеми. Інколи одна з груп може виступати в ролі судді. Кожна група розробляє власний план вирішення однієї клінічної проблеми (наприклад, комплексне лікування генералізованого пародонтиту обох щелеп). Студент у кожній з груп відстоює чи доповнює колективну думку групи. Цей метод інтерактивного навчання можна реалізувати шляхом:

- дискусіі;

- диспуту;

(ㄱ В. В. Федько, У. Д. Матолич, А. В. Нетлюх, Р. В. Гайдук 
- дебатів чи “круглого столу”;

- створення проблемної ситуації та ії розв' язку через рольову гру $[7,8]$.

Залежно від етапів семінарського заняття, викладач виконує певні дії. Під час підготовчого етапу пояснює студентам суть та варіанти практичного впровадження методу інтерактивного навчання. Допомагає студентам сформувати групи, забезпечити професійними алгоритмами, запитаннями й клінічними задачами різних рівнів складності, рентгенограмами, даними лабораторних досліджень та мікрофільмами-презентаціями.

Під час основного етапу - слідкує за ходом дискусії, відмічає адекватність вирішення клінічної проблеми конкуруючими чи корпоративними групами, виявляє студента-лідера, який пропонує найбільш точний і раціональний варіант вирішення проблеми та підвищує загальний результат групи.

Під час заключного етапу — оцінює результат творчої роботи кожної групи, оцінює кожного студента за виробленими критеріями оцінювання.

Для реалізації поставлених цілей семінарського заняття, на основі методу конкурентних або корпоративних груп, ми використовували тести і ситуаційні

\section{Література}

1. Мухина С. А. Современные инновационные технологии обучения / С. А. Мухина, А. А. Соловьёва. - М. : ГЭОТАР-Медиа, 2008. - 360 с.

2. Протоколи надання стоматологічної допомоги. - Київ, 2005. - C. 146-148.

3. Данилевський М. Ф. Терапевтична стоматологія / М. Ф. Данилевський, А. В. Борисенко, А. М. Політун. - К. : Медицина, 2008. - Т. 3 : Захворювання пародонта. -615 с.

4. Навчання: нові стратегії розвитку/ упоряд. Г. Сиротенко. - К. : Шк. світу, 2007. — 128 с. — (Б-ка “Шк. світу”).

5. Ігри дорослих. Інтерактивні методи навчання/ упоряд. Л. Галіцина. - К. : Ред. загальнопед. газ., 2005. - 128 с. (Б-ка “Шк. світу”).

6. Енциклопедія педагогічних технологій та інновацій / ав- задачі другого і третього рівнів, рентгенограми, історії хвороби, слайди, фільми, нетипові ситуаційні задачі, тематичних хворих. Студенти проводили обстеження хворого $з$ патологією пародонта, гігієнічну обробку зубів та кюретаж пародонтальних кишень, асистували під час клаптевої операції у конкретного хворого. Разом із викладачем призначали загальне та місцеве лікування хворого, виписували рецепти на медикаменти, навчали пацієнта засобів гігієни порожнини рота [2, 3, 9].

Висновки. Під час роботи в конкурентних або корпоративних групах студенти:

- набувають досвіду командної роботи, конструктивного дискутування, культури спілкування та колегіальності;

- в процесі поетапної дискусії вступають у взаємодію, обмінюються думками, набутим раніше досвідом, як у власній групі, так і з членами конкурентної або корпоративної групи;

- пропонують власне вирішення проблеми;

вчаться аргументовано відстоювати свою точку зору та дослухатися до інших, у процесі пошуку оптимального вирішення проблеми, що й складає суть інтерактивного спілкування та навчання.

тор-укладач Н. П. Наволокова. — Х. : Вид. група “Основа”, 2010. — 176 c. - (Серія “Золота педагогічна скарбниця”).

7. Пометун О. Сучасний урок. Інтерактивні технології навчання : наук.-метод. посібник / О. Пометун, Л. Пироженко. - К. : Вид-во “А. С. К.”, 2004. - 192 с.

8. David Leigh. Designing and Delivery Training for Groups. Kogan Page Ltd., p. 224 ; Ли Д. Практика группового тренинга / Д. Ли. -СПб. : Питер, 2002. — 224 с. : ил. —(Серия “Эффективный тренинг”).

9. Тимофеев А. А. Руководство по челюстно-лицевой хирургии и хирургической стоматологии / А. А. Тимофеев. - Киев : ООО “Червона Руга-Турс”, 1998. - Т. II. - С. 7 20. 